\title{
ARTICLES
}

Submitted 01.21.2018. Approved 09.03.2018

Evaluated through a double-blind review process. Scientific Editor: Pablo Isla

Original version

DOI: http://dx.doi.org/10.1590/So034-759020190202

\section{THE MISSING LINK BETWEEN HIGH PERFORMANCE WORK PRACTICES AND PERCEIVED ORGANIZATIONAL POLITICS}

\author{
O elo perdido entre o sistema de trabalho de alto desempenho e a percepção \\ de política organizacional
}

\author{
El eslabón perdido entre prácticas laborales de alto rendimiento y percepción \\ de la política organizacional
}

\begin{abstract}
A vast majority of research characterizes organizational politics as an aversive phenomenon and thus recommends exploring the factors that minimize its intensity. This study primarily endeavored to examine the role of high performance work practices (HPWPs) in controlling organizational politics. The moderating influence of Machiavellian personalities on HPWPs- politics was also evaluated. Through a questionnaire survey, 243 responses were obtained from engineers working in a local industrial area of capital city of Pakistan. The results showed an inverse relationship between HPWPs and perceived organizational politics (POP), and the moderating role of Machiavellianism was substantiated. Practical implications are presented based on the study results.
\end{abstract}

KEYWORDS | High performance work practices, Machiavellian, perceived organizational politics, engineering sector, time-lagged study.

\section{RESUMO}

\section{ADNAN RIAZ}

adnanriaz.aiou@gmail.com ORCID: 0000-0001-8185-9316

\section{SAIMA BATOOL ${ }^{2}$}

saimabatool601@gmail.com

ORCID: 0000-0003-2655-2607

MOHD SHAMSURI MD SAAD ${ }^{3}$

shamsuri@utem.edu.my

ORCID: 0000-0002-2269-5494

${ }^{1}$ Allama Iqbal Open University, Department of Business Administration, Islamabad, Pakistan

${ }^{2}$ Army Public College of Management and Sciences, Islamabad, Pakistan

3Universiti Teknikal Malaysia Melaka, Melaka, Malaysia
A grande maioria das pesquisas caracteriza a política organizacional como um fenômeno aversivo, portanto recomenda que sejam explorados os fatores para minimizar a sua intensidade. Este estudo objetivou principalmente examinar o papel das práticas do Sistema de Trabalho de Alto Desempenho (STAD) no controle da política organizacional. A influência moderadora das personalidades maquiavélicas também foi avaliada noS STAD em relação à percepção de política na organização (PPO). Por meio de questionário, foram obtidas 243 respostas de engenheiros que trabalham na área industrial local. Os resultados mostraram uma relação inversa entre STAD e PPO. Da mesma forma, o papel moderador do maquiavelismo foi confirmado. A discussão e as implicações práticas são apresentadas com base nos resultados do estudo.

PALAVRAS-CHAVE / Práticas de trabalho de alto desempenho, maquiavelismo, percepção de política na organização, setor de engenharia, estudo demorado.

\section{RESUMEN}

Una vasta mayoría de investigaciones caracteriza a las políticas organizacionales como un fenómeno aversivo, por consiguiente, recomendado para explorar los factores para minimizar la intensidad. Este estudio intenta primariamente analizar el papel de las prácticas laborales de alto rendimiento (high performance work practices [HPWPS]) en controlar las políticas organizacionales. La influencia moderadora de personalidades maquiavélicas también se evaluó en HPWPs para la relación de políticas percibidas. A través de una encuesta con cuestionario, se obtuvieron 243 respuestas de ingenieros que trabajan en el área industrial local. Los resultados presentados mostraron una relación inversa entre HPWPs y la percepción de la política organizacional. Asimismo se corroboró el papel moderador del maquiavelismo. El debate y las implicaciones prácticas se presentan con base en los resultados del estudio.

PALABRAS CLAVE / Prácticas laborales de alto rendimiento, maquiavelismo, percepción de la política organizacional, sector de ingeniería, estudio retrasado. 


\section{INTRODUCTION}

Organizational politics has been a key topic of discussion since many decades, primarily for two reasons. First, politics is inevitable and prevails with varying intensity, irrespective of the nature, culture, and size of the organization (Witt, Andrews, \& Kacmar, 2000). Second, politics is mostly perceived to be harmful, so there is a need to address it by exploring its causes (Meisler \& Vigoda-Gadot, 2014). Various organizational and job-related factors have been highlighted as key antecedents of organizational politics. Despite categorical studies on minimizing politicking in the organization, extant research lacks any clear understanding of the impact of high performance work practices (HPWPs) on organizational politics. Previous studies highlight the role of certain human resources (HR) practices to control organizational politics (commonly measured as perceived organizational politics [POP]). However, HPWPs are not used as a holistic construct to predict POP, as pointed out by Atinc, Darrat, Fuller, and Parker (2010). Since organizations have keenly realized the importance of HR practices to cope with adversities and future challenges (Paré \& Tremblay, 2007; Peacock, 2017), this study would help to address the negative effects of organizational politics by applying a specific set of key HPWPs.

Organizations of all types have to face politics in their working environments in different forms (Bodla \& Danish, 2009). Initially, research in this particular domain was more focused on examining the nature, causes, and consequences of politics in broad sectors and regional areas. By accepting politics as a reality of organizational life, recently, researchers' focus has shifted to examining models of organizational politics among professional groups, such as nurses (Basar \& Basim, 2016), teachers (Gibson, 2006), and frontline hotel employees (Karatepe, Babakus, \& Yavas, 2012) -especially groups that are largely responsible for the success and failure of any organization. Engineers and employees involved in highly specialized tasks are more vulnerable to politics because of their resource dependence and dominant role in organizational life.

By contrast, relationships between organizationallevel factors and outcomes are susceptible to personality and dispositional factors (Kooij et al., 2013; Sendjaya, Pekerti, Härtel, Hirst, \& Butarbutar, 2016). For most of the early management researches, researchers focused on possible moderators changing the strengths and directions of the relationships (Dawson, 2014). Neglecting situational factors may challenge the causal relationships. Relationships between HPWPs and outcomes may vary due to individual differences. Previous studies have shown the Machiavellian dark side of personality attributes, wherein these personalities not only involve themselves in political maneuverings but are also considered the proponents of politics (Kacmar, Bozeman, Carlson, \& Anthony, 1999; O'connor \& Morrison, 2001). Therefore, it would be interesting to scrutinize the HPWPs-POP association for Machiavellian and nonMachiavellian personalities. The environment plays an important role in shaping personalities (Göllner et al., 2017) . Machiavellian (or Mach) tendencies are believed to be developed in retrenched environments (Tucker, Lowman, \& Marino, 2016). Particularly, culture plays an important role in developing and helping Dark Triad personalities (O’Boyle, Forsyth, Banks, \& McDaniel, 2012). It would be interesting to observe the extent to which engineers show Mach tendencies and how these tendencies affect the postulated HPWPs-POP relationship.

In sum, this study contributes in different ways. First, although organizational politics has been an area of interest for various scholars, the relationship between HPWPs as a consolidated measure and POP is yet to be established (Atinc, Darrat, Fuller, \& Parker, 2010). Second, Mach has been conclusively found to be a key personality trait that perceives and exercises politics in the organization (Valle \& Perrewe, 2000). In this study, Mach's role as a moderator is explored on the postulated relationship. Lastly, this study also strives to satisfy the concern of Hofstede and Hofstede (2005) who categorically emphasized that theories and research findings should be generalized cautiously. Dissimilarities among countries with respect to cultural dimensions recommend the need for country-specific findings. Hence, this study conducts detailed analysis of the impact of HPWPs on POP with the moderating role of Machiavellianism among employees working as engineers.

\section{LITERATURE REVIEW}

\section{HPWPs}

HPWPs are defined as a set of consistent, integrated, and interdependent HR practices (Guthrie, 2001; Huselid \& Becker, 1995; Pfeffer, 1998; Zacharatos, Barling, \& Iverson, 2005). They play an important role in developing organizational competencies and promoting a social relationship among employees (Shin \& Konrad, 2017). Therefore, organizations need to know the specific bundle of HPWPs that best suits their requirements and helps them acquire the desired competencies (Posthuma, Campion, Masimova, \& Campion, 2013). According to Harley, Allen, and Sargent (2007), it is difficult to determine the best combination of HPWPs. However, some examples of HPWPs include procedural hiring, training and skill development opportunities, compensation, decision-making participation, flexible working hours, information sharing, empowerment, and job design 
(Combs, Liu, Hall, \& Ketchen, 2006; Rabl, Jayasinghe, Gerhart, \& Kühlmann, 2014). For this study, we follow Bamberger, Biron, and Meshoulam (2014)'s integrated HPWPs model comprising selective recruitment, training and development, career progression, internal promotions, job guarantee, target-based performance, incentives and rewards, and active participation.

As summarized by Ma, Long, Zhang, Zhang, and Lam (2017), HPWPs play a significant role in fostering social harmony among organizational employees. The focus of this study is to validate the link between HPWPs and positive organizational behavior by examining engineers who are generally thought to be professionals and responsible for organizational success and failure (Hiebert, 2001; Lobontiu, 2010). Following the tenet of the social exchange theory (Blau, 1964), organizations offering the best HR bundles are basically developing psychological reservoirs for the employees to face workplace challenges. Employees feel honored upon receiving extra care from the organization and may reciprocate accordingly during deleterious situations (Gouldner, 1960).

\section{POP}

POP is defined as the extent to which employees perceive political behavior and maneuvering in their work environment that lead to unjust and unfair results (Ferris, Russ, \& Fandt, 1989). It is widely believed that individual behavior is the outcome of perception rather than reality itself (e.g., Gandz \& Murray, 1980; Porter, Crampon, \& Smith, 1976). Empirical results also support the strong association between perceived reality and employees' actions and performances (Purves, Morgenstern, \& Wojtach, 2015). This is the reason POP has resulted in adverse consequences. For example, Ferris et al. (1998) concluded that POP led to employees' withdrawal behavior, reduced job involvement, job anxiety, and job dissatisfaction. Some other empirical evidences found POP to be an antecedent to psychological strain, job dissatisfaction, low performance, and low organizational citizenship behavior (Chang, Rosen, \& Levy, 2009; Miller, Rutherford, \& Kolodinsky, 2008). To counter organizational politics, a number of factors have been highlighted. For example, a transparent and fair environment, role clarity, growth opportunities, and resourcefulness are among the few factors to control POP (Muhammad, 2007; Poon, 2003; Thau \& Mitchell, 2010; Valle \& Perrewe, 2000).

\section{HPWPs and POP}

The shared mental model (SMM) explicates the mutually held assumptions and perceptions that correspond with collective conduct (Fiore, Salas, \& Cannon-Bowers, 2001). SMMs display a dominant influence over individuals' behavior (Maynard \& Gilson, 2014). Unique and consistent HPWPs such as extensive staffing, training, decentralization, open communication, and performance-oriented compensation result in shared feelings of care, equality, support, responsiveness, and trust in the organization. This subsequently reduces the perception of inequality, favoritism, and self-serving behavior, which are termed as organizational politics in organizational behavior literature. Employees also have a shared understanding of the procedures, practices, and policies of the organization, as well as the type of behaviors that are desired and appreciated. Organizational support ultimately refrains them from exhibiting any illegitimate behavior not sanctioned by the organizational authorities (Bowen \& Ostroff, 2004). Thus, we may hypothesize the following:

H1: HPWPs may reduce the POP in the organization.

\section{Mach Personality}

The Mach is an antagonistic and hostile personality trait (Christie, Geis, Festinger, \& Schachter, 2013). Wilson, Near, and Miller (1996) defined Machiavellianism as a strategy to manipulate others for one's self-interest even at the cost of the others. Machs are intrinsically inclined to be manipulative, conniving, and deceptive. They use other people as stepping-stones to pursue their own agenda. Studies ascertain that Machs have strong interpersonal skills to influence people, which they use optimally to manipulate and persuade others (Belschak, Muhammad, \& Den Hartog, 2016; Cohen, 2018).

\section{Mach Personality and POP}

According to Adams, Treadway, and Stepina (2008), personality traits are the most influential factors for predicting POP, compared to any other personal variable. This is because they stimulate the pattern of how employees identify and understand organizational politics. Machs are perceived to be strongly related to POP, because high-Machs have an innate tendency to understand human instincts and can do almost anything to promote their self-interest (Bereczkei, 2017). According to Sussman, Adams, Kuzmits, and Raho (2002), high-Machs can exercise different impression management and political tactics to obtain results for personal success and growth. Previous researchers have shown a strong positive relationship between Machiavellianism and POP (O'connor \& Morrison, 2001; Valle \& Perrewe, 2000). The famous model of POP presented by Ferris et al. (1989) also characterizes Mach personalities as the strong predictors of POP. 
Later, the study of Stepanski, Kershaw, and Arkakelian (2000) also supported this relationship. Hence, we may assume the following:

H2: Machiavellianism significantly influences POP.

\section{A Machiavellian as Moderator between HPWPs and POP}

Machs are thoroughly concerned with advancing their selfinterest while disregarding organizational well-being (Sakalaki, Richardson, \& Thépaut, 2007). They may exercise a variety of influence tactics for building political connections, including deliberate self-disclosure and intimidation (Elias, 2015). In a colloquial sense, the political atmosphere becomes characteristically risky, signifying that those who hoard supremacy and inspiration may enjoy success (Christie et al., 2013; Pilch \& Turska, 2015; Ruiz-Palomino \& Bañón-Gomis, 2016). In organizational life, Ferris et al. (1989) claimed that Machs are the proponents and predecessors of political behaviors. Recently, a few empirical findings concluded that Machiavellianism is a strong predictor of incivility (Furtner, Maran, \& Rauthmann, 2017), poor job performance (Blickle, Schütte, \& Genau, 2018), counterproductive work behaviors (Cohen, 2018), and workplace bullying (Pilch \& Turska, 2015). It has already been tested as a moderator between various organizationally desired relationships in different settings (Reimers \& Barbuto, 2002; Wei \& Chen, 2012; Zagenczyk et al., 2013). Machs, being self-promoting in nature, disregard any contribution from either an individual, group, or organization. Their self-centered ideology forbids them from acknowledging the support given by the organization (Bereczkei, 2017). Based on these arguments, we may reasonably assume the following:

$\mathrm{H}_{3}$ : Machs moderate the relationship between HPWPs and POP such that the relationship is weaker for individuals who have high-Mach tendencies.

\section{METHODOLOGY}

\section{Subjects / Sample}

The objective of this study was to examine the POP among qualified engineers in association with HPWPs at their workplace. Qualified engineers for this survey comprised employees who (a) worked on permanent (full-time) basis, (b) had one year of job experience, (c) and whose supervisors had conducted at least one performance appraisal of them. The sample frame was drawn from the HR departments of the respective organizations, while the selection of respondents was based on the simple random sampling method. The contacts of the second author helped us throughout the questionnaire administration process, being incumbent in the HR department of one of the organizations. The engineering job involves relatively more administrative conflicts as it is highly technical and focused, has over-arching goals, and must provide support services to diverse customers (Leckie, Pettigrew, \& Sylvain, 1996). The POP can be held at any hierarchical level, and therefore engineers working at different hierarchical levels constituted the population of the study.

The questionnaire was divided into two parts with a covering letter explaining the purpose of study, strict confidentiality measures, and contact information of the principal investigator. The first part was about the items related to HPWPs and Machiavellianism, whereas the second part was about measuring POP. Since the data were collected at two different points of time, both parts contained demographical information of the respondents with a unique code assigned for further match making. Considering the level of understanding of engineers, all the measures were in English and adopted from tested and authentic sources. The questionnaires were distributed in sealed envelopes through either postal mail or focal persons responsible for administering them within their organizations. To ensure confidentiality, the survey was anonymous, and the respondents were required not to reveal their identities. Moreover, to control the social desirability response, respondents' participation in the survey was voluntary, and they could leave at any point during the data collection process. Furthermore, respondents could send the questionnaire directly to the principal investigator if they wished to do so.

This was basically a time-lagged study. In the first interval (T1), respondents were required to fill part-I. Then, after one month (T2), part-II had to be filled in along with the demographical part. Unique codes assigned to each questionnaire helped us to make a match, while demographical information further validated the same respondents.

A sample size of 250 and above is deemed appropriate to test the postulated relationships (MacCallum, Widaman, Zhang, \& Hong, 1999). Therefore, more than 400 questionnaires were distributed to the target population using email and the local postage service. At T1, a total of 288 questionnaires were received, which were subsequently recorded using IBM SPSS 20.0. After T2, a total of 243 responses were received. Thus, 243 total responses were analyzed to test the hypotheses. Studies conducted in the Asian context generally reflect a high response rate (Abbas, Raja, Darr, \& Bouckenooghe, 2014). A few questionnaires were dropped from the analysis based on the following shortcomings (not attempted in true spirit): 
- Incomplete responses,

- $\quad$ Reverse entries cautions, and

- $\quad$ Delayed responses / responses received much later than the stipulated one-month time period.

The demographic data show that $59 \%$ of the respondents belonged to the information technology department, and a majority were males (92\%). Around $55 \%$ respondents were aged between 31 to 40 years. The sample data also revealed that $72 \%$ of respondents had acquired a master's degree, and $83 \%$ were in middle-level job positions. The data also reflected considerable variation in the service duration, as $39 \%$ had 6-10 years' service, $37 \%$ had 10 or more years of service, and $18 \%$ had $1-5$ years of service length. Moreover, $17 \%$ of respondents had income of $\$ 600-\$ 700,42 \%$ had income of $\$ 700-\$ 800$, and $22 \%$ had income of $\$ 800-\$ 900$.

\section{Measures}

All the statements were anchored on a five-point Likert scale ranging from 1 (strongly disagree) to 5 (strongly agree).

\section{POP}

POP was measured using the 12 items on the POP scale from the study of Kacmar and Ferris (1991). This shorter version has helped different studies and was found reliable by Kacmar and Carlson (1997) $(a=0.87)$ and Vigoda and Cohen (2002) $(a=0.77)$.

\section{Machiavellianism}

To measure the Mach personality, five items were taken from the study of Christie and Geis (1970). Each respondent (engineer) was asked to specify the magnitude of his or her agreement with every item. This smaller version was also found reliable by Christie and Geis (1970) with $a=0.87$.

\section{HPWPs}

Following the suggestion of Becker and Huselid (1998), different researchers (Delery \& Shaw, 2001; Guest, 1999) had combined the measurements of various HR practices to form the consolidated HPWPs items set. Following the same analogy, a scale comprising 27 items was adopted from Bamberger and Meshoulam (2000) to measure the unified HPWPs. The scale had already been found reliable $(a=0.76)$ by Sun, Aryee, and Law (2007).

\section{Control Variables}

In the current study, two demographical factors, that is, Income and Service Duration showed significant effects on POP and were used as control variables. A one-way analysis of variance comparing POP across Income ( $\mathrm{F}=3.44$, p<0.005) and Service Duration $(\mathrm{F}=3.003, p<0.005)$ revealed significant differences in the outcome variable.

\section{RESULTS}

\section{Scale Validity and Reliability}

Reliability of constructs was ascertained by calculating the Cronbach's alpha, which was higher than 0.93 for all constructs above the threshold of 0.7 (Nunnally \& Bernstein, 1994). However, Cronbach's alpha has been criticized for being oversimplified and a lower-bound statistic to gauge true reliabilities. Therefore, composite reliabilities (CR) were also evaluated, which, if higher than 0.7, indicate good reliability (Churchill, 1979; Hair, Black, Babin, Anderson, \& Tatham, 1998). The CR values in our study range from 0.95 to 0.97 , indicating relatively good reliabilities of the measured constructs.

The construct validity of the measurement model was evaluated with the help of confirmatory factor analysis (Hair et al., 1998) using the AMOS program Version-18. Convergent validity of the measurement was ensured by examining the standardized factor loadings and average variance extracted (AVE). The factor loadings ranged from 0.51 to 0.81 ( $p<0.05$ ), satisfying the criteria prescribed by Bagozzi and Yi (1991). Secondly, the AVE of all three constructs were above 0.5 (Hair et al., 1998), which shows that more than $50 \%$ of the variance of the measurement items can be accounted for by the latent variables.

To assess discriminant validity, Fornell and Larcker (1981) recommended considering the AVE, which, if higher than the squared correlation or maximum shared variance, provides evidence of discriminant validity. For variance-based models, Hair, Black, Babin, Anderson, and Tatham (2010) advised the use of the square-root value of the AVE to compare the inter-construct correlations. The bivariate correlations between all constructs ranged from 0.01 to 0.51 , far below the corresponding AVE and square-root of AVE. Table 1 ensures the discriminant validity based on all these criteria. In sum, both the convergent and discriminant validities confirmed the overall construct validity. Having such qualities, the researcher could safely move toward testing the proposed hypotheses. 
Table 1. Results of confirmatory factor analysis

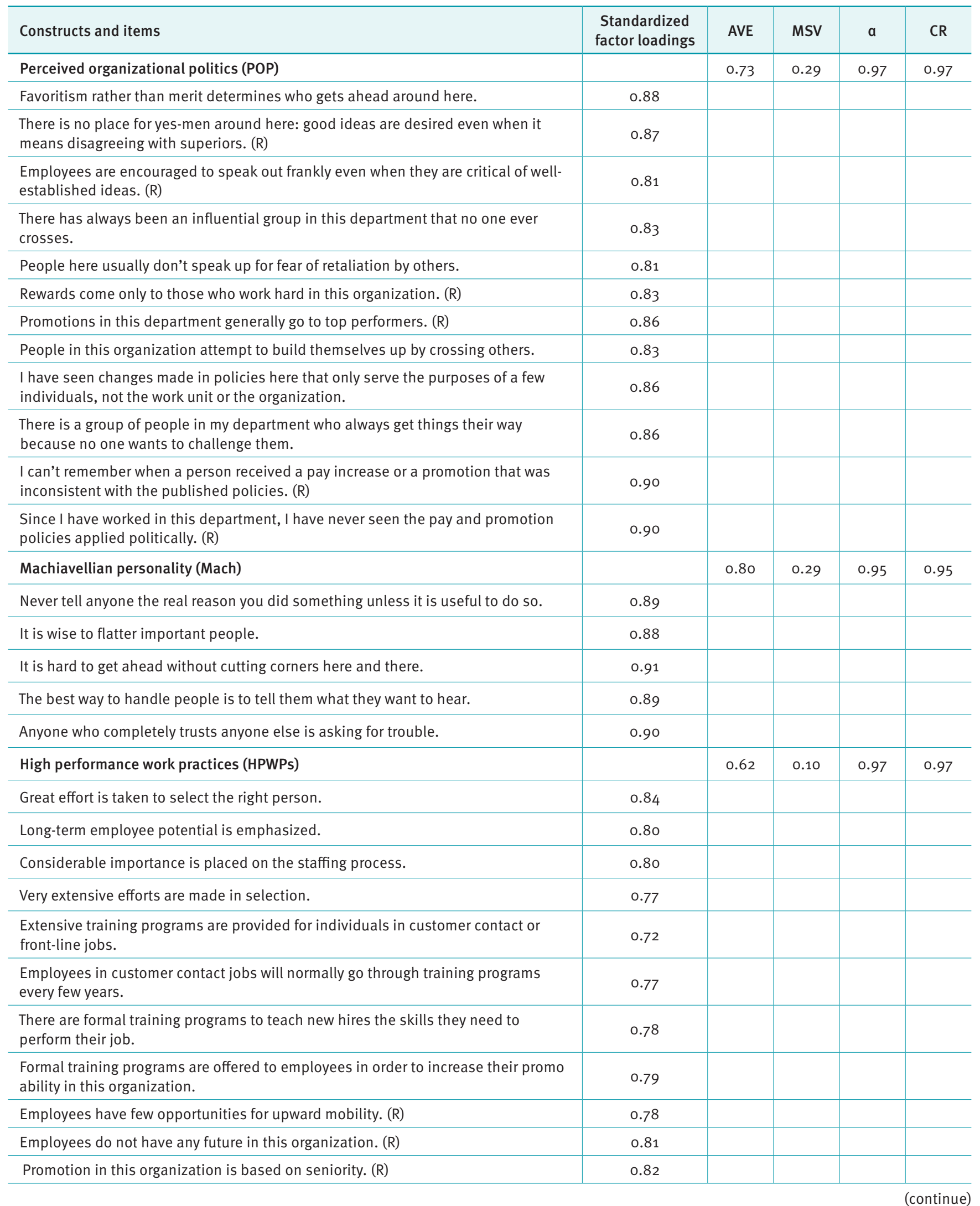


Table 1. Results of confirmatory factor analysis

(conclusion)

\begin{tabular}{|c|c|c|c|c|c|}
\hline Constructs and items & $\begin{array}{l}\text { Standardized } \\
\text { factor loadings }\end{array}$ & AVE & MSV & a & $\mathrm{CR}$ \\
\hline Employees have clear career paths in this organization. & 0.77 & & & & \\
\hline $\begin{array}{l}\text { Employees in this job can be expected to stay with this organization for as long as } \\
\text { they wish }\end{array}$ & 0.78 & & & & \\
\hline The duties in this job are clearly defined. & 0.79 & & & & \\
\hline This job has an up-to-date description. & 0.87 & & & & \\
\hline $\begin{array}{l}\text { The job description for a position accurately describes all of the duties performed } \\
\text { by individual employees. }\end{array}$ & 0.80 & & & & \\
\hline Individuals in this job receive bonuses based on the profit of the organization. & 0.86 & & & & \\
\hline There is close tie or matching of pay to individual/group performance. & 0.79 & & & & \\
\hline Employees in this job are often asked by their supervisor to participate in decisions. & 0.72 & & & & \\
\hline Individuals in this job are allowed to make decisions. & 0.75 & & & & \\
\hline $\begin{array}{l}\text { Employees are provided the opportunity to suggest improvements in the way things } \\
\text { are done. }\end{array}$ & 0.76 & & & & \\
\hline Supervisors keep open communications with employees in this job. & 0.85 & & & & \\
\hline
\end{tabular}

Note: $\mathrm{R}=$ reverse-coded item. The standardized factor loadings were significant at the 0.05 level. AVE= average variance extracted; $\mathrm{MSV}=$ maximum shared variance; $\mathrm{a}=$ Chronbach's alpha; $C R=$ composite reliability.

\section{Hypothesis Testing}

Table 2 shows the results of the descriptive statistics, bivariate correlations, and composite reliabilities. The HPWPs' correlation with POP $(r=-0.274, p<0.01)$ is significant and in the assumed direction. Similarly, Machs significantly correlate with POP $(r=0.514$, $p<0.01)$. All the measures were found to be reliable as given in the diagonal.

Table 2. Means, standard deviations, correlations, and reliabilities

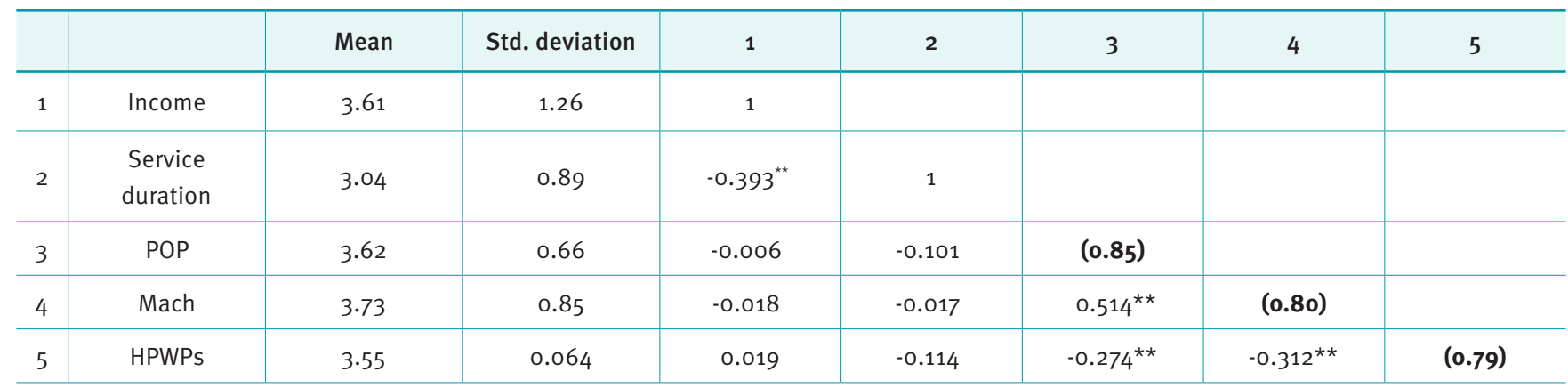

Note: $\mathrm{N}=243$. The diagonal elements (boldface) are the square root of the average variance extracted. POP = perceived organizational politics; HPWPS = high performance work practices; Mach $=$ Machiavellian personality. ${ }^{* *} p<0.05 ;{ }^{*} p<0.01 ;{ }^{* * *} p<0.001$.

Results of the multiple linear regression given in Table 3 revealed HPWPs as significant predictors of POP $(\beta=-0.144, p$ r $0.05)$, which confirmed Hypothesis 1. Similarly, Mach was also found to be a significant predictor of POP $(\beta=0.364, p<0.001)$, thus confirming Hypothesis 2. 
Likewise, Hypothesis 3 stated that Mach would moderate the relationship between HPWPs and POP such that the relationship would be weaker for high-Mach personalities compared with lowMachs. To validate Hypothesis 3, the moderated multiple regression analyses technique was used (Cohen, Cohen, West, \& Aiken, 2013). In the first step, the control variables were entered (income and service duration), followed by the independent and moderator variables in the second step. In the third step, we entered the interacting term calculated by multiplying the independent and moderator variables (HPWPs x Mach), which, if significant, confirmed moderation. By following all these steps, the effect of the interacting term (HPWPs $x$ Mach) on POP was significant $(\beta=0.352$, $p=\langle 0.001$, thus confirming Hypothesis 3.

\section{Table 3. Results of the main effects and moderated regression analysis}

\begin{tabular}{|c|c|c|}
\hline & \multicolumn{2}{|c|}{ Perception of politics } \\
\hline & $\beta$ & $\Delta \mathrm{R}^{2}$ \\
\hline \multicolumn{3}{|l|}{ Step 1} \\
\hline Income & -0.052 & \\
\hline Service duration & -0.001 & 0.010 \\
\hline \multicolumn{3}{|l|}{ Step 2} \\
\hline Income & -0.056 & \\
\hline Service duration & -0.002 & \\
\hline Mach & $0.364^{\star * *}$ & \\
\hline HPWPS & $-0.144^{*}$ & $0.28^{\star * *}$ \\
\hline \multicolumn{3}{|l|}{ Step 3} \\
\hline Income & -0.068 & \\
\hline Service duration & 0.017 & \\
\hline Mach & $0.274^{\star \star \star}$ & \\
\hline HPWPs & $-0.372^{\star \star \star}$ & \\
\hline HPWPs x Mach & $0.352^{\star * \star}$ & $0.099^{* * *}$ \\
\hline
\end{tabular}

Note: $n=243$. HPWPS = high performance work practices; Mach = Machiavellian personality. ${ }^{*} p<0.05 ;{ }^{* \star} p<0.01 ;{ }^{* \star *} p<0.001$.

We plotted the significant interactions for the high and low $(M+S D)$ values of the moderator. Plots of the significant interactions are displayed in Graph 1, which shows that the negative relationship of HPWPs-POP was stronger when the Mach was high. Simple slope tests using the procedure recommended by Aiken and West (1991) showed that the slope for low levels of Mach was significant $(\beta=-0.66, p<.001)$ compared with individuals with high-Mach personality $(\beta=0.08 ; n s)$.
Graph 1. Interactive effects of HPWPs and Mach on POP

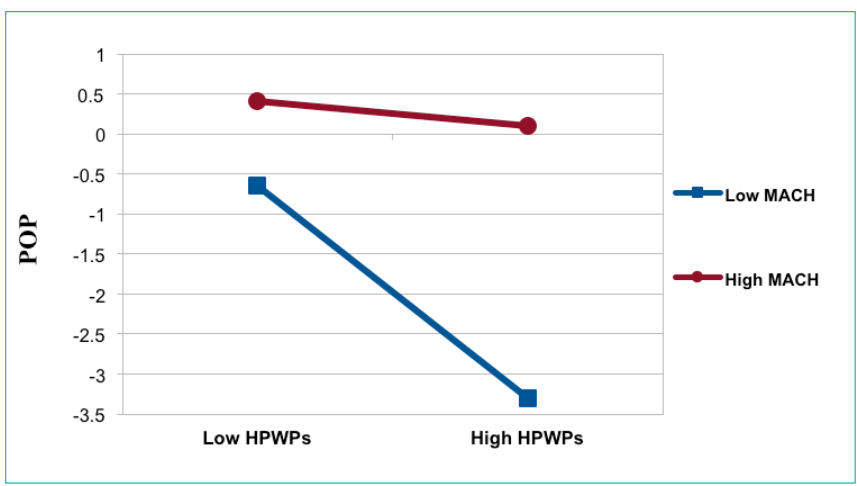

Note: HPWPs = high performance work practices; $\mathrm{POP}=$ perceived organizational politics.

\section{DISCUSSION}

Employees belonging to technical domains have different aspirations, needs, and job requirements (Hernaus \& Mikulić, 2014). Engineers and technical staff are treated as the key functional group in any organization. Considering the unique nature of engineers' job profile, role expectations, and likely challenges, the engineering sector becomes an interesting segment to study organizational politics. This study primarily investigated the impact of HPWPs on POP. This was recommended by Atinc et al. (2010) in his famous meta-analytical review as a fruitful area for research. In addition, the moderating role of Mach personalities was also examined on the HPWPs-POP relationship.

The results revealed a significantly inverse relationship between HPWPS and POP. Moreover, the moderating role of Machiavellianism was confirmed on the HPWPs to POP relationship. It is important to note that the above relationship had not been studied so far, even though Ferris et al. (1998) generally explored an association between a few HR practices and POP.

As the results indicate, HPWPs significantly reduce POP in organizations. This is consistent with the finding that HPWPs can offer a win-win situation for organizations and employees (Machin \& Wood, 2005). Organizations emphasizing HPWPs usually have a more contented and satisfied workforce (Appelbaum, 2000; Guest, 1999; Hall, Hochwarter, Ferris, \& Bowen, 2004). This in turn leads to strong attitudinal development and behavioral affiliation, thus controlling the POP among employees (Drory \& Vigoda-Gadot, 2010).

Our measurement to gauge HPWPs synthesized items including recruitment and selection, career management, job security, role clarity, performance management, participation in decision making, and open communication. A reasonable match was obtained between the demographical information of respondents and the results. For example, most of the employees 
had worked for around 10 years in their organizations, and the majority were mid-career workers. At this level, employees usually have ample clarity about work roles and responsibilities, enjoy job security, and get opportunities to participate in important decisions. In open and secure environments, any feeling about political maneuvering is diffused. Our analysis provides evidence of the effectiveness of performance management systems in engineering organizations. Political behavior, perception, and tendencies are naturally reduced when employees are goal oriented and strive to achieve excellence. Our results further show that respondents had acquired 16 years of education, which is necessary to carry out the highly specialized engineering tasks. Reasonable education and training opportunities help employees to develop skills and competencies. It has been proved that if organizations are responsive to employees' needs, they become a cornerstone in coping with cynical attitudes about the organizational environment (Chiaburu, Peng, Oh, Banks, \& Lomeli, 2013).

We believe that our judgment would bolster this line of thought and affirm that HPWPs can be helpful in alleviating POP and political activities in the organization. The inverse relationship between HPWPs and POP is also in line with the conclusion drawn by Van De Voorde \& Beijer (2015), which suggests that HPWPs help to control aversive conditions.

The results of this study further confirm that a Mach personality moderates the inverse relationship between HPWPs and POP among employees. The ideology of Machiavelli presented around 500 years ago still poses a challenge to managers and practitioners in organizational life. High-Machs have the genetic tendency to perceive their environment as thoroughly politicized, where everyone is pursuing their self-interest (Mohtadi, 2013; Sibia, 2016). Since a man is the product of his environment (Young, 2012), becoming involved in political behavior is quite natural. High-Machs exert pressure using various means and look at ways to extend their political affiliations (Furnham, Richards, \& Paulhus, 2013). Political settings are characteristically uncertain, signifying that power and influence will be the key to their rise (Hall et al., 2004). Thus, people with high-Mach personalities translate activities and occasions into political terms (Buchanan \& Badham, 2008) and tend to capitalize political situations for maximizing their personal interests (Czibor \& Bereczkei, 2012). Analysts also highlight that Machiavellianism entails gathering the negative perspectives about human instinct, becoming involved in unethical practices, and utilizing different manipulative strategies to fulfill one's objectives (Johns, Xie, \& Fang, 1992). However, regardless of these instinctive hypothetical associations between Mach and POP, very little conclusive investigation has overtly scrutinized the moderating influence. Our results invite attention from managers, as the majority of respondents were male. The Machiavellian trait is highly gender specific, and male workers usually exhibit such attitudinal and behavioral manifestations (Ali, Amorim, \& Chamorro-Premuzic, 2009; Fehr \& Samsom, 2013). Considering our findings, HPWPs may lose their impact on individual outcomes in cases of high-Machiavellian personalities. In addition, a vast majority of research on HR practices and perceived politics originates from the U.S. and European countries, which are different in terms of cultural dimensions (Hofstede, 2003). Our investigation is an answer to the call of Giorgi, Lockwood, and Glynn (2015) to understand the context of the models and established relationships. Overall, our findings are in line with the existing empirical evidence reported on the western culture, which is marked high in individualism and low in power distances. Thus, we may conclude that the organizationally desirable outcomes resulting from HPWPs and POP are less susceptible to cultural differences and are well generalized in Pakistan, a country marked high in power distance and collectivism. The results of this study could be a significant building block for understanding and controlling politics in various cross-cultural settings, especially within the Pakistani and South Asian organizational context. For further generalization, future research needs to be conducted in different cultures and industries.

\section{THEORETICAL IMPLICATIONS}

Our study has extended the research of the organizational politics domain in various ways. First, we conceptualized the effects of HPWPs on POP, which were not deliberated much in the extant research. Second, this study confirmed the moderating role of Mach personalities on the HPWPs-POP relationship. The study examined all the relationships by collecting data from the engineering sector of Pakistan. Recent focus of the researchers in organizational behavior domain is shifted over to examining organizational politics with respect to a specific population. Hence, engineers working in local industries constituted a unique area of investigation.

\section{PRACTICAL IMPLICATIONS}

Our results provide a sound base to control politics in the professional work environment. Managers should be cautious about the harmful effects of workplace politics. They should consider all potential means, such as clear governing rules, regulations and policies, open communication supported by feedback and guidance, developmental opportunities, and 
an attractive career path to address political maneuvering. Organizations should revisit their hiring processes by focusing on personality tests to induct employees. New inductees should have positive and authentic personality traits. For existing employees, training interventions may help to reshape personality traits by developing positivity and harmony.

\section{STRENGTHS, LIMITATIONS, AND FUTURE DIRECTIONS}

Similar to other studies conducted in social sciences, this study also has a few limitations. Considering the unique nature of the engineering sector, the implications of this study should be treated with caution. Other workgroups may have different perceptions about the variables of interest and can come up with different strengths and directionality of the relationships. Second, we explored the relationship between HPWPS and POP in the presence of the Mach personality only, while future research may go further by integrating other Dark Triad personalities (narcissism and psychopathy) as moderating variables. Similarly, they may concentrate on a different set of HPWPs to determine their impacts on POP. Moreover, this study was conducted in Pakistan. As Pakistan exhibits different socio-economic conditions, future research may be conducted in neighboring countries and in other parts of Asia as well to compare results.

\section{REFERENCES}

Abbas, M., Raja, U., Darr, W., \& Bouckenooghe, D. (2014). Combined effects of perceived politics and psychological capital on job satisfaction, turnover intentions, and performance. Journal of Management, 4O(7), 1813-1830. doi:10.1177/0149206312455243

Adams, G. L., Treadway, D. C., \& Stepina, L. P. (2008). The role of dispositions in politics perception formation: The predictive capacity of negative and positive affectivity, equity sensitivity, and selfefficacy. Journal of Managerial Issues, 20(4), 545-563.

Aiken, L., \& West, S. (1991). Multiple regression: Testing and interpreting interactions. Newbury Park, CA: Sage.

Ali, F., Amorim, I. S., \& Chamorro-Premuzic, T. (2009). Empathy deficits and trait emotional intelligence in psychopathy and Machiavellianism. Personality and Individual Differences, 47(7), 758-762. doi:10.1016/j. paid.2009.06.016

Appelbaum, E. (2000). Manufacturing advantage: Why high-performance work systems pay off. New York, NY: Cornell University Press.

Atinc, G., Darrat, M., Fuller, B., \& Parker, B. W. (2010). Perceptions of organizational politics: A meta-analysis of theoretical antecedents. Journal of Managerial Issues, 22(4), 494-513.

Bagozzi, R. P., \& Yi, Y. (1991). Multitrait-multimethod matrices in consumer research. Journal of Consumer Research, 17(4), 426-439.
Bamberger, P., Biron, M., \& Meshoulam, I. (2014). Human resource strategy: Formulation, implementation, and impact. New York, NY: Routledge.

Bamberger, P., \& Meshoulam, I. (2000). Human resource management strategy. London, UK: Sage.

Basar, U., \& Basim, N. (2016). A cross-sectional survey on consequences of nurses' burnout: Moderating role of organizational politics. Journal of Advanced Nursing, 72(8), 1838-1850. doi:10.1111/jan.12958

Becker, B. E., \& Huselid, M. A. (1998). High performance work systems and firm performance: A synthesis of research and managerial implications. Research in Personnel and Human Resource Management, $16,53-101$

Belschak, F. D., Muhammad, R. S., \& Den Hartog, D. N. (2016). Birds of a feather can butt heads: When Machiavellian employees work with Machiavellian leaders. Journal of Business Ethics, 151(3), 613-626. doi:10.1007/s10551-016-3251-2

Bereczkei, T. (2017). Machiavellianism: The psychology of manipulation. New York, NY: Routledge.

Blau, P. M. (1964). Exchange and power in social life. New York, NY: Wiley.

Blickle, G., Schütte, N., \& Genau, H. A. (2018). Manager psychopathy, trait activation, and job performance: A multi-source study. European Journal of Work and Organizational Psychology, 27(4), 450-461.

Bodla, M. A., \& Danish, R. Q. (2009). Politics and workplace: An empirical examination of the relationship between perceived organizational politics and work performance. South Asian Journal of Management, 16(1), 44 .

Bowen, D. E., \& Ostroff, C. (2004). Understanding HRM-firm performance linkages: The role of the "strength" of the HRM system. Academy of Management Review, 29(2), 203-221. doi:10.2307/20159029

Buchanan, D., \& Badham, R. (2008). Power, politics, and organizational change: Winning the turf game. London, UK: Sage.

Chang, C.-H., Rosen, C. C., \& Levy, P. E. (2009). The relationship between perceptions of organizational politics and employee attitudes, strain, and behavior: A meta-analytic examination. Academy of Management Journal, 52(4), 779-801. doi:10.5465/amj.2009.43670894

Chiaburu, D. S., Peng, A. C., Oh, I.-S., Banks, G. C., \& Lomeli, L. C. (2013). Antecedents and consequences of employee organizational cynicism: A meta-analysis. Journal of Vocational Behavior, 83(2), 181 197. doi:10.1016/j.jvb.2013.03.007

Christie, R., \& Geis, F. (1970). Studies in Machiavellianism, New York: Academic Press.

Christie, R., Geis, F. L., Festinger, L., \& Schachter, S. (2013). Studies in Machiavellianism (Social Psychology Monographs), Kindle Edition: Academic Press.

Churchill, G. A. Jr. (1979). A paradigm for developing better measures of marketing constructs. Journal of Marketing Research, 16(1), 64-73. doi: $10.2307 / 3150876$

Cohen, A. (2018). Counterproductive work behaviors: Understanding the dark side of personalities in organizational Life. New York, NY: Routledge.

Cohen, J., Cohen, P., West, S. G., \& Aiken, L. S. (2013). Applied multiple regression/correlation analysis for the behavioral sciences. New York, NY: Routledge. 
Combs, J., Liu, Y., Hall, A., \& Ketchen, D. (2006). How much do highperformance work practices matter? A meta-analysis of their effects on organizational performance. Personnel Psychology, 59(3), 501528. doi:10.1111/j.1744-6570.2006.00045.x

Czibor, A., \& Bereczkei, T. (2012). Machiavellian people's success results from monitoring their partners. Personality and Individual Differences, 53(3), 202-206. doi:10.1016/j.paid.2012.03.005

Dawson, J. F. (2014). Moderation in management research: What, why, when, and how. Journal of Business and Psychology, 29(1), 1-19. doi:10.1007/s10869-013-9308-7

Delery, J. E., \& Shaw, J. D. (2001). The strategic management of people in work organizations: Review, synthesis, and extension. In G. R. Ferris (Ed.), Research in personnel and human resources management (Vol. 20, pp. 165-197). Stamford, CT: JAI Press.

Drory, A., \& Vigoda-Gadot, E. (2010). Organizational politics and human resource management: A typology and the Israeli experience. Human Resource Management Review, 20(3), 194-202. doi:10.1016/j. hrmr.2009.08.005

Elias, R. Z. (2015). The effects of Machiavellianism and cultural dimensions on business students' general distrust of corporations. Journal of Business Studies Quarterly, 6(4), 21-30.

Fehr, B., \& Samsom, D. (2013). The construct of Machiavellianism: Twenty years later. In C. D. Spielberger \& J. N. Butcher (Eds.), Advances in personality assessment (pp. 77-116). Hillsdale, NJ: Lawrence Erlbaum Associates.

Ferris, G. R., Arthur, M. M., Berkson, H. M., Kaplan, D. M., Harrell-Cook, G., \& Frink, D. D. (1998). Toward a social context theory of the human resource management-organization effectiveness relationship. Human Resource Management Review, 8(3), 235-264. doi:10.1016/ S1053-4822(98)90004-3

Ferris, G. R., Russ, G. S., \& Fandt, P. M. (1989). Politics in organizations. In R. A. Giacalone \& P. Rosenfeld (Eds.), Impression management in the organization (pp. 143-170). Hillsdale, NJ: Lawrence Erlbaum Associates.

Fiore, S. M., Salas, E., \& Cannon-Bowers, J. A. (2001). Group dynamics and shared mental model development. In M. London (Ed.), Applied in psychology: How people evaluate others in organizations (pp. 309336). Mahwah, NJ: Lawrence Erlbaum Associates Publishers.

Fornell, C., \& Larcker, D. F. (1981). Evaluating structural equation models with unobservable variables and measurement error. Journal of Marketing Research, 18(1), 39-50. doi:10.2307/3151312

Furnham, A., Richards, S. C., \& Paulhus, D. L. (2013). The dark triad of personality: A 10 year review. Social and Personality Psychology Compass, 7(3), 199-216. doi:10.1111/spc3.12018

Furtner, M. R., Maran, T., \& Rauthmann, J. F. (2017). Dark leadership: The role of leaders' dark triad personality traits. In M. Clark, \& C. Gruber (Eds), Leader Development Deconstructed (pp. 75-99). Cham, Switzerland: Springer.

Gandz, J., \& Murray, V. V. (1980). The experience of workplace politics. AcademyofManagementJournal, 23(2), 237-251. doi:10.2307/255429
Gibson, S. K. (2006). Mentoring of women faculty: The role of organizational politics and culture. Innovative Higher Education, 31(1), 63-79. doi:10.1007/s10755-006-9007-7

Giorgi, S., Lockwood, C., \& Glynn, M. A. (2015). The many faces of culture: Making sense of 30 years of research on culture in organization studies. The Academy of Management Annals, 9(1), 1-54. doi:10.5465 /19416520.2015.1007645

Göllner, R., Roberts, B. W., Damian, R. I., Lüdtke, O., Jonkmann, K., Trautwein, U. (2017). Whose "storm and stress" is it? Parent and child reports of personality development in the transition to early adolescence. Journal of Personality, 85(3), 376-387. doi:10.1111/ jopy. 12246

Gouldner, A. W. (1960). The norm of reciprocity: A preliminary statement. American Sociological Review, 25(2) 161-178. doi:10.2307/2092623

Guest, D. E. (1999). Human resource management-the workers' verdict. Human Resource Management Journal, 9(3), 5-25. doi:10.1111/j.1748-8583.1999.tboo200.x

Guthrie, J. P. (2001). High-involvement work practices, turnover, and productivity: Evidence from New Zealand. Academy of Management Journal, 44(1), 180-190. doi:10.2307/3069345

Hair, J. F., Black, W. C., Babin, B. J., Anderson, R. E., \& Tatham, R. L. (2010). Multivariate data analysis (vol. 5). Upper Saddle River, NJ: Prentice Hall.

Hall, A. T., Hochwarter, W. A., Ferris, G. R., \& Bowen, M. G. (2004). The dark side of politics in organizations. In R. W. Griffin, A. O'Leary-Kelly, \& R. D. Pritchard (Eds.), The dark side of organizational behavior (pp. 237-261). San Francisco, CA: Wiley.

Harley, B., Allen, B. C., \& Sargent, L. D. (2007). High performance work systems and employee experience of work in the service sector: The case of aged care. British Journal of Industrial Relations, 45(3), 607633. doi:10.1111/j.1467-8543.2007.00630.x

Hernaus, T., \& Mikulić, J. (2014). Work characteristics and work performance of knowledge workers. EuroMed Journal of Business, 9(3), 268-292. doi:10.1108/EMJB-11-2013-0054

Hiebert, M. (2001). Powerful professionals: Getting your expertise used inside your organization. Victoria, B.C.: Trafford Publishing.

Hofstede, G. (2003). Cultural constraints in management theories. In D. C. Thomas (Ed.), Readings and cases in international management: A cross-cultural perspective (pp. 17-27). Thousand Oaks, CA: Sage Publications.

Hofstede, G., \& Hofstede, G. (2005). Culture and organizations: Software of the mind. New York, NY: McGraw-Hill.

Huselid, M. A., \& Becker, B. E. (1995). The strategic impact of high performance work systems. Paper presented at the Academy of Management annual meeting, Vancouver.

Johns, G., Xie, J. L., \& Fang, Y. (1992). Mediating and moderating effects in job design. Journal of Management, 18(4), 657-676. doi:10.1177/014920639201800404

Kacmar, K. M., Bozeman, D. P., Carlson, D. S., \& Anthony, W. P. (1999). An examination of the perceptions of organizational politics model: Replication and extension. Human Relations, 52(3), 383-416. doi:10.1177/001872679905200305

Kacmar, K. M., \& Carlson, D. S. (1997). Further validation of the perceptions of politics scale (POPS): A multiple sample investigation. Journal of Management, 23(5), 627-658. doi:10.1016/S01492063(97)90019-2 
Kacmar, K. M., \& Ferris, G. R. (1991). Perceptions of organizational politics scale (POPS): Development and construct validation. Educational and Psychological Measurement, 51(1), 193-205. doi:10.1177/0013164491511019

Karatepe, O. M., Babakus, E., \& Yavas, U. (2012). Affectivity and organizational politics as antecedents of burnout among frontline hotel employees. International Journal of Hospitality Management, 31(1), 66-75. doi:10.1016/j.ijhm.2011.04.003

Kooij, D. T. A. M., Guest, D. E., Clinton, M., Knight, T., Jansen, P. G. W., \& Dikkers, J. S. E. (2013). How the impact of HR practices on employee well-being and performance changes with age. Human Resource Management Journal, 23(1), 18-35. doi:10.1111/1748-8583.12000

Leckie, G. J., Pettigrew, K. E., \& Sylvain, C. (1996). Modeling the information seeking of professionals: A general model derived from research on engineers, health care professionals, and lawyers. The Library Quarterly, 66(2), 161-193.

Lobontiu, N. (2010). System dynamics for engineering students: Concepts and applications. Burlington, MA: Elsevier Science.

Ma, Z., Long, L., Zhang, Y., Zhang, J., \& Lam, C. K. (2017). Why do highperformance human resource practices matter for team creativity? The mediating role of collective efficacy and knowledge sharing. Asia Pacific Journal of Management, 34(3), 565-586. doi:10.1007/s10490017-9508-1

MacCallum, R. C., Widaman, K. F., Zhang, S., \& Hong, S. (1999). Sample size in factor analysis. Psychological Methods, 4(1), 84-99. doi:10.1037/1082-989X.4.1.84

Machin, S., \& Wood, S. (2005). Human resource management as a substitute for trade unions in British workplaces. ILR Review, 58(2), 201-218.

Maynard, M. T., \& Gilson, L. L. (2014). The role of shared mental model development in understanding virtual team effectiveness. Group \& Organization Management, 39(1), 3-32. doi:10.1177/1059601113475361

Meisler, G., \& Vigoda-Gadot, E. (2014). Perceived organizational politics, emotional intelligence and work outcomes: Empirical exploration of direct and indirect effects. Personnel Review, 43(1), 116-135. doi:10.1108/PR-02-2012-0040

Miller, B. K., Rutherford, M. A., \& Kolodinsky, R. W. (2008). Perceptions of organizational politics: A meta-analysis of outcomes. Journal of Business and Psychology, 22(3), 209-222. doi:10.1007/s10869-008 9061-5

Mohtadi, M. F. (2013). Man and his environment. Proceedings of the Second International Banff Conference on Man and His Environment. Held in Banff, Canada, May 19-22, 1974. Great Britain, Elsevier Science.

Muhammad, A. H. (2007). Antecedents of organizational politics perceptions in Kuwait business organizations. Competitiveness Review: An International Business Journal, 17(4), 234-247. doi:10.1108/10595420710844325

Nunnally, J. C., \& Bernstein, I. (1994). Validity. In: Psychometric Theory. 3rd edn. Toronto: McGraw-Hill, Inc.

O’Boyle, E. H., Jr., Forsyth, D. R., Banks, G. C., \& McDaniel, M. A. (2012). A meta-analysis of the dark triad and work behavior: A social exchange perspective. Journal of Applied Psychology, 97(3), 557-579. doi:10.1037/a0025679
O'connor, W. E., \& Morrison, T. G. (2001). A comparison of situational and dispositional predictors of perceptions of organizational politics. The Journal of Psychology, 135(3), 301-312. doi:10.1080/00223980109603700

Paré, G., \& Tremblay, M. (2007). The influence of high-involvement human resources practices, procedural justice, organizational commitment, and citizenship behaviors on information technology professionals' turnover intentions. Group \& Organization Management, 32(3), 326 357. doi:10.1177/1059601106286875

Peacock, M. J. (2017). The human resource professional's guide to change management: Practical tools and techniques to enact meaningful and lasting organizational change. New York, NY: Business Expert Press.

Pfeffer, J. (1998). The human equation: Building profits by putting people first. London, UK: Harvard Business Press.

Pilch, I., \& Turska, E. (2015). Relationships between Machiavellianism, organizational culture, and workplace bullying: Emotional abuse from the target's and the perpetrator's perspective. Journal of Business Ethics, 128(1), 83-93. doi:10.1007/s10551-014-2081-3

Poon, J. M. (2003). Situational antecedents and outcomes of organizational politics perceptions. Journal of Managerial Psychology, 18(2), 138-155. doi:10.1108/02683940310465036

Porter, L. W., Crampon, W. J., \& Smith, F. J. (1976). Organizational commitment and managerial turnover: A longitudinal study. Organizational Behavior and Human Performance, 15(1), 87-98. doi:10.1016/0030-5073(76)90030-1

Posthuma, R. A., Campion, M. C., Masimova, M., \& Campion, M. A (2013). A high performance work practices taxonomy: Integrating the literature and directing future research. Journal of Management, 39(5), 1184-1220. doi:10.1177/0149206313478184

Purves, D., Morgenstern, Y., \& Wojtach, W. T. (2015). Perception and reality: Why a wholly empirical paradigm is needed to understand vision. Frontiers in Systems Neuroscience, 9, 156. doi:10.3389/ fnsys.2015.00156

Rabl, T., Jayasinghe, M., Gerhart, B., \& Kühlmann, T. M. (2014). A metaanalysis of country differences in the high-performance work systembusiness performance relationship: The roles of national culture and managerial discretion. Journal of Applied Psychology, 99(6), 10111041. doi:10.1037/a0037712

Reimers, J. M., \& Barbuto, J. E., Jr. (2002). A framework exploring the effects of the Machiavellian disposition on the relationship between motivation and influence tactics. Journal of Leadership \& Organizational Studies, 9(2), 29-41. doi:10.1177/107179190200900203

Ruiz-Palomino, P., \& Bañón-Gomis, A. (2016). The negative impact of chameleon-inducing personalities on employees' ethical work intentions: The mediating role of Machiavellianism. European Management Journal, 35(1), 102-115. doi:10.1016/j.emj.2016.02.010

Sakalaki, M., Richardson, C., \& Thépaut, Y. (2007). Machiavellianism and economic opportunism. Journal of Applied Social Psychology, 37(6), 1181-1190. doi:10.1111/j.1559-1816.2007.00208.x

Sendjaya, S., Pekerti, A., Härtel, C., Hirst, G., \& Butarbutar, I. (2016). Are authentic leaders always moral? The role of Machiavellianism in the relationship between authentic leadership and morality. Journal of Business Ethics, 133(1), 125-139. doi:10.1007/s10551-014-2351-0

Shin, D., \& Konrad, A. M. (2017). Causality between high-performance work systems and organizational performance. Journal of Management, 43(4), 973-997. doi:10.1177/0149206314544746 
Sibia, C. (2016). A product of my environment. London, UK: London's Finest Distribution.

Stepanski, K., Kershaw, T., \& Arkakelian, A. (2000). Perceptions of work politics: Meta-analytic investigation of individual differences and outcome variables. Paper presented at the Fifteenth Annual Conference of the Society for Industrial and Organizational Psychology, New Orleans.

Sun, L.-Y., Aryee, S., \& Law, K. S. (2007). High-performance human resource practices, citizenship behavior, and organizational performance: A relational perspective. Academy of Management Journal, 50(3), 558-577. doi:10.5465/amj.2007.25525821

Sussman, L., Adams, A.J., Kuzmits, F.E., \& Raho, L.E.(2002). Organizational politics: Tactics, channels, and hierarchical roles. Journal of Business Ethics, 40(4), 313-329. doi:10.1023/A:1020807700478

Thau, S., \& Mitchell, M. S. (2010). Self-gain or self-regulation impairment? Tests of competing explanations of the supervisor abuse and employee deviance relationship through perceptions of distributive justice. Journal of Applied Psychology, 95(6), 1009-1031. doi:10.1037/a0020540

Tucker, R. L., Lowman, G. H., \& Marino, L. D. (2016). Dark triad traits and the entrepreneurial process: A person-entrepreneurship perspective. In M. R. Buckley, J. R. B. Halbesleben, \& A. R. Wheeler, Research in Personnel and Human Resources Management (pp. 245-290). Emerald Group Publishing Limited.

Valle, M., \& Perrewe, P. L. (2000). Do politics perceptions relate to political behaviors? Tests of an implicit assumption and expanded model. Human Relations, 53(3), 359-386. doi:10.1177/0018726700533004
Van De Voorde, K., \& Beijer, S. (2015). The role of employee HR attributions in the relationship between high-performance work systems and employee outcomes. Human Resource Management Journal, 25(1), 62-78. doi:10.1111/1748-8583.12062

Vigoda, E., \& Cohen, A. (2002). Influence tactics and perceptions of organizational politics: A longitudinal study. Journal of Business Research, 55(4), 311-324. doi:10.1016/S0148-2963(00)00134-X

Wei, H.-S., \& Chen, J.-K. (2012). The moderating effect of Machiavellianism on the relationships between bullying, peer acceptance, and school adjustment in adolescents. School Psychology International, 33(3), 345-363. doi:10.1177/0143034311420640

Wilson, D. S., Near, D., \& Miller, R. R. (1996). Machiavellianism: A synthesis of the evolutionary and psychological literatures. Psychological Bulletin, 119(2), 285-299. doi:10.1037/00332909.119.2.285

Witt, L. A., Andrews, M. C., \& Kacmar, K. M. (2000). The role of participation in decision-making in the organizational politicsjob satisfaction relationship. Human Relations, 53(3), 341-358. doi:10.1177/0018726700533003

Young, D. (2012). Being a product of your environment. Denver, CO: Outskirts Press.

Zacharatos, A., Barling, J., \& Iverson, R. D. (2005). High-performance work systems and occupational safety. Journal of Applied Psychology, 9o(1), 77-93. doi:10.1037/0021-9010.90.1.77

Zagenczyk, T. J., Cruz, K. S., Woodard, A. M., Walker, J. C., Few, W. T., Kiazad, K., \& Raja, M. (2013). The moderating effect of Machiavellianism on the psychological contract breach-Organizational identification/ disidentification relationships. Journal of Business and Psychology, 28(3), 287-299. doi:10.1007/s10869-012-9278-1 